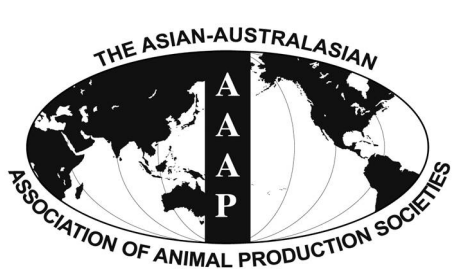

Open Access

Asian Australas. J. Anim. Sci.

Vol. 29, No. 8 : 1159-1165 August 2016

http://dx.doi.org/10.5713/ajas.15.0701

www.ajas.info

pISSN 1011-2367 elSSN 1976-5517

\title{
Relationship between Molecular Structure Characteristics of Feed Proteins and Protein In vitro Digestibility and Solubility
}

\author{
Mingmei Bai $^{1,2}$, Guixin Qin ${ }^{1,2, *}$, Zewei Sun ${ }^{1,2, *}$, and Guohui Long ${ }^{3}$ \\ ${ }^{1}$ Animal Production and Product Quality and Security Key Lab, Ministry of Education, \\ Jilin Agricultural University, Changchun 130118, China
}

\begin{abstract}
The nutritional value of feed proteins and their utilization by livestock are related not only to the chemical composition but also to the structure of feed proteins, but few studies thus far have investigated the relationship between the structure of feed proteins and their solubility as well as digestibility in monogastric animals. To address this question we analyzed soybean meal, fish meal, corn distiller's dried grains with solubles, corn gluten meal, and feather meal by Fourier transform infrared (FTIR) spectroscopy to determine the protein molecular spectral band characteristics for amides I and II as well as $\alpha$-helices and $\beta$-sheets and their ratios. Protein solubility and in vitro digestibility were measured with the Kjeldahl method using $0.2 \% \mathrm{KOH}$ solution and the pepsin-pancreatin two-step enzymatic method, respectively. We found that all measured spectral band intensities (height and area) of feed proteins were correlated with their the in vitro digestibility and solubility $(\mathrm{p} \leq 0.003)$; moreover, the relatively quantitative amounts of $\alpha$-helices, random coils, and $\alpha$-helix to $\beta$-sheet ratio in protein secondary structures were positively correlated with protein in vitro digestibility and solubility $(\mathrm{p} \leq 0.004)$. On the other hand, the percentage of $\beta$-sheet structures was negatively correlated with protein in vitro digestibility ( $<<0.001)$ and solubility $(\mathrm{p}=0.002)$. These results demonstrate that the molecular structure characteristics of feed proteins are closely related to their in vitro digestibility at $28 \mathrm{~h}$ and solubility. Furthermore, the $\alpha$-helix-to- $\beta$-sheet ratio can be used to predict the nutritional value of feed proteins. (Key Words: Feed, Protein, Protein In vitro Digestibility, Fourier Transform Infrared Spectroscopy, Molecular Structure Characteristics, Protein Solubility)
\end{abstract}

\section{INTRODUCTION}

Nutritional value of protein in feedstuff not only depends on its amino acid content and composition proportion, but also on its molecular structure characteristics (Peng et al., 2014). Recent studies have highlighted the importance of determining the relationship between molecular spectral band characteristics of proteins and their intestinal absorption so as to clarify the mechanism of nitrogen supplementation (Qin et al., 2014).

\footnotetext{
* Corresponding Authors: G. X. Qin. Tel: +86-13843052917, Fax:

+86-0431-87914888, E-mail: qgx@jlau.edu.cn / Zewei Sun. Tel: +86-13504436949, E-mail: sunzewei@jlau.edu.cn

2 College of Animal Science and Technology, Jilin Agricultural University, Changchun 130118, China.

3 College of Life Science, Jilin Agricultural University, Changchun 130118, China.

Submitted Aug. 25, 2015; Revised Oct. 19, 2015; Accepted Nov. 11, 2015
}

The traditional method of determining the nutritional value of feeds involves destroying the three-dimensional structure of constituent proteins by acid or alkali treatment or by mechanical polishing, and then using so-called wet chemical methods to determine chemical composition. However, this approach provides no information at a molecular level on the nutritional value of feeds or on their capacity for digestion by livestock. Fourier transform infrared (FTIR) technique is a powerful tool for analyzing the structure of feed proteins (Xin et al., 2013a), which allows investigators to predict how they are processed and absorbed within the animals' digestive tract. However, there is certainly difficulty to use FTIR spectrum for quantifying the tertiary structure having higher portion of side chains of the conventional feedstuffs protein.

Recent studies have shown a close correlation between the molecular structure characteristics of feed proteins and their nutritional value (Yu and Nuez-Ortín, 2010; Samadi et 
al., 2013). Specifically, $\alpha$-helices and $\beta$-sheets in the protein secondary structures can affect digestibility of feed proteins (Dyson and Wright, 1993). Certain features (amide I and II bands) of protein molecular structures of corn distiller's dried grains with solubles (corn DDGS) from various sources were correlated with intestinal protein digestibility, which can be used to predict the absorption of essential nutrients by the small intestine (Chen et al., 2014). Another study found that spectral band intensity characteristics of proteins affect protein quality, nutrient utilization, and digestion in dairy cows (Doiron et al., 2009). Therefore, establishing a relationship between the molecular structure characteristics of conventional feed proteins and their nutritional value will strengthen the current knowledge on protein nutritional value and broaden the scope of molecular spectroscopy as a bioanalytical tool for rapidly assessing the nutritive value of feed proteins.

To our knowledge, the relationship between molecular structure characteristics of conventional feed proteins and protein solubility (PS) and in vitro digestibility in monogastric animals has not been previously investigated. The objectives of this study were i) to assess protein molecular structure characteristics of conventional feed proteins by FTIR; ii) to examine the PS and in vitro digestibility of these proteins; and iii) to quantify the relationship between protein molecular structure characteristics and PS as well as in vitro digestibility.

\section{MATERIALS AND METHODS}

\section{Sample preparation and treatment}

Five conventional feed ingredients (soybean meal, fish meal, corn DDGS, corn gluten meal, and feather meal) were provided by Changchun Wellhope Animal Husbandry Co. (Changchun, China). All feed samples used in this experiment were collected from raw commodities and stored according to commodity storage standard, one month of storage period. One half of each sample was ground in the laboratory mill through a $1 \mathrm{~mm}$ screen for laboratory analysis and sub-samples ( $\mathrm{n}=3$ per type of feed) was collected and stored at $4^{\circ} \mathrm{C}$. The other half was stored as a backup at $-20^{\circ} \mathrm{C}$. Chemical profiles of the five feeds are presented in Table 1.

\section{Determination of protein solubility}

PS was determined according to the method as described by Dale (1987). Feedstuff sample with $1.5 \mathrm{~g}$ was placed in a $100 \mathrm{~mL}$ conical flask, and then added $75 \mathrm{~mL}$ of $0.2 \%(\mathrm{w} / \mathrm{v})$ potassium hydroxide solution; the mixture was stirred on a magnetic stirrer for $20 \mathrm{~min}$ and then transferred to a $50 \mathrm{~mL}$ tube and centrifuged at 2,700 rpm for $10 \mathrm{~min} .15$ $\mathrm{mL}$ volume of supernatant was measured by the chemical method (AOAC, 1990), yielding an amount equivalent to $0.3 \mathrm{~g}$ of original sample $(15 / 75=x / 1.5 \mathrm{~g}$, where $x=0.3 \mathrm{~g})$. PS (\%) was calculated as crude protein (CP) content in 15 $\mathrm{mL}$ supernatant/CP content of the original sample $\times 100 \%$.

\section{Determination of protein in vitro digestibility}

Protein in vitro digestibility was evaluated according to a method as previously described by Boisen and Fernandez (1995). Feedstuff sample with $1.0 \mathrm{~g}$ (accurate to $0.001 \mathrm{~g}$ ) was placed in a $100 \mathrm{~mL}$ conical flask, and then added 10 $\mathrm{mL}$ of $0.01 \mathrm{M}$ hydrochloric acid $(\mathrm{pH} 2.0)$ and pepsin solution containing $1.0 \mathrm{mg}$ porcine pepsin (product no. P7000; Sigma, St. Louis, MO, USA). To prevent bacterial growth, $0.5 \mathrm{~mL}$ of chloramphenicol solution consisting of $0.5 \mathrm{~g}$ chloramphenicol (product no. 0230; Amresco, Solon, $\mathrm{OH}, \mathrm{USA}$ ) in $100 \mathrm{~mL}$ ethanol was added to the mixture, followed by incubation for $4 \mathrm{~h}$ at $37^{\circ} \mathrm{C}$. After neutralization with $0.2 \mathrm{M}$ sodium hydroxide, $10 \mathrm{~mL}$ of $0.2 \mathrm{M}$ phosphate buffer ( $\mathrm{pH} 6.8$ ) was added. The $\mathrm{pH}$ was adjusted to 6.8 with $1 \mathrm{M} \mathrm{HCl}$ or $1 \mathrm{M} \mathrm{NaOH}$, and the solution was mixed with 1 $\mathrm{mL}$ of a freshly prepared pancreatin solution containing 50 mg porcine pancreatin (product no.P7-545-100G; Sigma, USA). The flask was closed with a rubber stopper and incubated with continuous magnetic stirring at $39^{\circ} \mathrm{C}$ for 4,8 , $12,16,20,24$, and $28 \mathrm{~h}$, respectively. After adding $5 \mathrm{~mL}$ of $20 \%$ sulfosalicylic acid, the sample was centrifuged at $15,000 \mathrm{rpm}$ for $15 \mathrm{~min}$; the supernatant was discarded and the precipitate was heated at $80^{\circ} \mathrm{C}$ for $24 \mathrm{~h}$. CP digestibility (in \%) was calculated as $\mathrm{CP}$ content of the original sample $-\mathrm{CP}$ content of precipitate/CP content of the original sample $\times 100 \%$.

Table 1. Chemical profiles of five conventional feed ingredients (dry matter basic)

\begin{tabular}{lrrrrr}
\hline Item & Soybean meal & Fish meal & Corn DDGS & Corn gluten meal & Feather meal \\
\hline Dry matter (\%) & $98.12 \pm 0.05^{\mathrm{a}}$ & $98.42 \pm 0.03^{\mathrm{b}}$ & $97.84 \pm 0.11^{\mathrm{c}}$ & $98.55 \pm 0.02^{\mathrm{b}}$ & $98.01 \pm 0.03^{\mathrm{ac}}$ \\
Ash (\%) & $6.39 \pm 0.16^{\mathrm{a}}$ & $16.85 \pm 0.03^{\mathrm{b}}$ & $5.49 \pm 0.47^{\mathrm{c}}$ & $1.72 \pm 0.05^{\mathrm{d}}$ & $2.82 \pm 0.01^{\mathrm{e}}$ \\
Ether extract (\%) & $1.32 \pm 0.02^{\mathrm{a}}$ & $7.14 \pm 0.18^{\mathrm{b}}$ & $4.79 \pm 0.21^{\mathrm{c}}$ & $3.68 \pm 0.04^{\mathrm{d}}$ & $2.42 \pm 0.04^{\mathrm{e}}$ \\
Crude protein (\%) & $43.35 \pm 0.02^{\mathrm{a}}$ & $66.86 \pm 0.02^{\mathrm{b}}$ & $28.36 \pm 0.03^{\mathrm{c}}$ & $63.18 \pm 0.01^{\mathrm{d}}$ & $85.49 \pm 0.03^{\mathrm{e}}$ \\
Total carbohydrate (\%) & $48.94 \pm 0.20^{\mathrm{a}}$ & $9.14 \pm 0.13^{\mathrm{b}}$ & $61.35 \pm 0.72^{\mathrm{c}}$ & $31.43 \pm 0.04^{\mathrm{d}}$ & $9.26 \pm 0.00^{\mathrm{b}}$ \\
\hline
\end{tabular}

Different lowercase letters in the same line indicate significant differences $(\mathrm{n}=3, \mathrm{p}<0.05)$.

Dried samples were analyzed for dry matter (Association of Official Analytical Chemists [AOAC], 1990; method 930.15), ash (AOAC, 1990; method 942.05), ether extract (AOAC, 1990; method 920.35), and crude protein (AOAC, 1990; method 984.13). Total carbohydrate content was calculated as (100\%-crude protein-ether extract-ash) (NRC, 2001). 


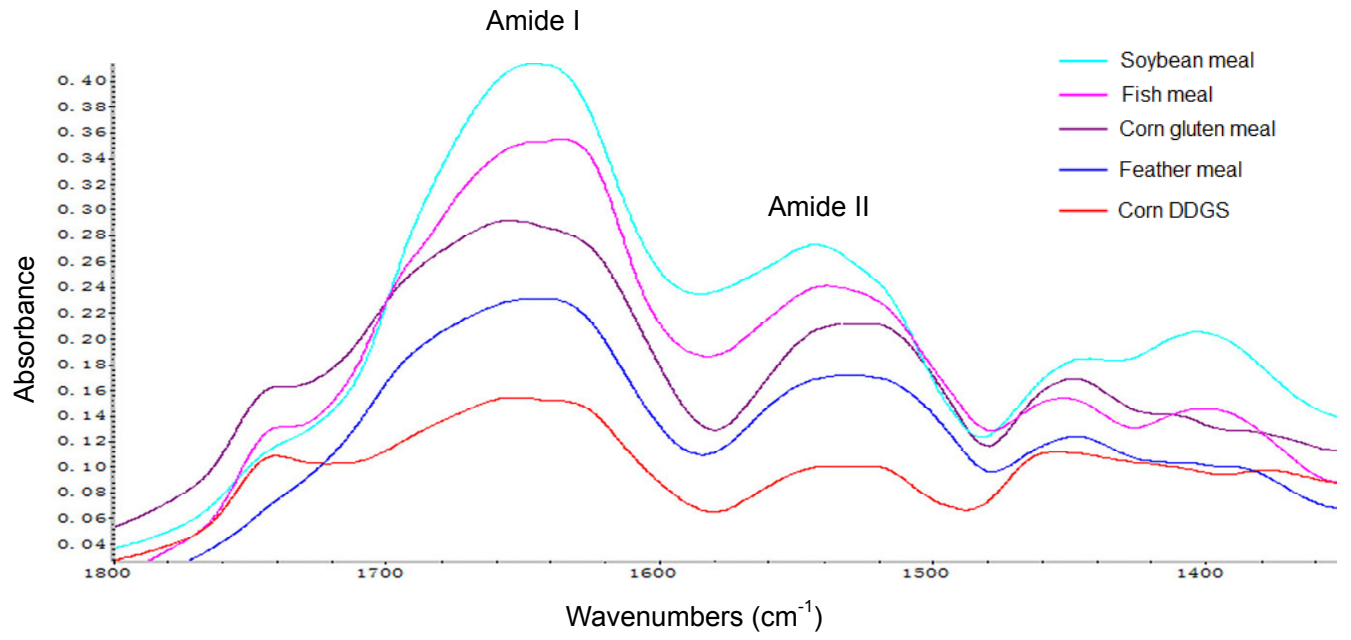

Figure 1. Fourier transform infrared (FTIR) spectra of five conventional feed ingredient proteins (baseline, $\sim 1,720$ to $1,479 \mathrm{~cm}^{-1}$ ). Wavenumbers are as follows: amide I height, $1,646 \mathrm{~cm}^{-1}$; amide II height, $1,542 \mathrm{~cm}^{-1}$; amide I area, 1,720 to $1,583 \mathrm{~cm}^{-1}$; and amide II area, 1,583 to $1,479 \mathrm{~cm}^{-1}$.

\section{Fourier transform infrared spectroscopy}

FTIR spectroscopy was performed according to the method as described by Long et al (2015). Briefly, $2 \mathrm{mg}$ of sample was mixed with $200 \mathrm{mg} \mathrm{KBr}$ in a vacuum dryer for $24 \mathrm{~h}$; the mixture was uniformly ground and pressed into a tablet (tablet thickness $=0.25 \mathrm{~mm}$; translucent shape) using an infrared (IR) tablet press (FW-4; Thermo Fisher Scientific, Waltham, MA, USA). FTIR spectra (FTIR8400 s; Shimadzu, Kyoto, Japan) were acquired in the midIR range $\left(4,000\right.$ to $\left.400 \mathrm{~cm}^{-1}\right)$ at a resolution of $4 \mathrm{~cm}^{-1}$ with 64 co-added scans. Each sample was run six times. As a control, a $\mathrm{KBr}$ pellet without protein was recorded under identical conditions. IR spectra were processed using OMNIC 8.0 software (Nicolet Analytical Instruments, Madison, WI, USA), and after baseline correction of the original map the sample and control spectra were compared. Amide I band narrowing was achieved with a full height of 38.2 and a resolution enhancement factor of 4.4. Fourier self-deconvolution using Origin 7.5 software (Origin Lab, Northampton, MA, USA) was used for Gaussian curve fitting in the region of the amide I band to separate overlapping bands. The secondary structure content of samples was detected from IR second-derivative amide I spectra by manually computing the relative peak areas under the bands assigned to a particular substructure.

\section{Statistical analysis}

Data were evaluated by analysis of variance with SPSS v.19.0.1 software (SPSS Inc., Chicago, IL, USA). The model used for protein molecular spectral band characteristics, $P S$ and in vitro digestibility analysis was $Y_{\mathrm{ij}}$ $=\mu_{\mathrm{i}}+\mathrm{e}_{\mathrm{ij}}$, where $\mathrm{Y}_{\mathrm{ij}}$ is an observation on the dependent variable $i j(i=1,2, \ldots, 5 ; j=1,2,3), \mu_{i}$ is the overall mean $(i=1,2, \ldots, 5)$, and $\mathrm{e}_{\mathrm{ij}}$ is the random error associated with the observation ij. Multiple comparisons of group means were carried out using Duncan's method. Results are expressed as mean \pm standard error, with $\alpha=0.05$ indicating a statistically significant difference. Correlation analysis was performed using Pearson's correlation coefficient with $95 \%$ confidence limits $(p<0.05)$.

\section{RESULTS}

\section{Protein spectral band intensities}

The protein IR spectrum showed two salient features, i.e., the amide I $\left(1,700\right.$ to $\left.1,600 \mathrm{~cm}^{-1}\right)$ and amide II $(1,600$ to $1,500 \mathrm{~cm}^{-1}$ ) bands (Figure 1). Results of the protein spectral band intensities analyses are presented in Table 2 . Significant differences were observed among feeds in terms of amide II heights and areas and amide I-to-II height and area ratios $(p<0.001)$. Soybean meal had the highest values for amide I and II heights, amide I and II areas, and amide I-to-II height and area ratios, whereas corn DDGS had the lowest values for all of these features.

\section{Protein secondary structures and solubility}

The Gaussian curve fitting analysis of the amide I band peak was carried out based on the preliminary study of Meng-Xia and Yuan (2002), showed characteristic peaks at 1,611 to $1,639 \mathrm{~cm}^{-1}$ that were attributed to $\beta$-sheets. Other peaks were observed that corresponded to the following structures: random coils, 1,640 to $1,649 \mathrm{~cm}^{-1}$; $\alpha$-helices, 1,650 to $1,658 \mathrm{~cm}^{-1}$; and $\beta$-turns, 1,660 to $1,700 \mathrm{~cm}^{-1}$ (Figure 2). Results of the protein secondary structures and solubility analyses are shown in Table 3 . Soybean meal had the highest percentage of $\alpha$-helices and random coil structures and $\alpha$-helix-to- $\beta$-sheet ratios; feather meal had the highest percentage of $\beta$-sheet structures; and corn DDGS had the highest percentage of $\beta$-turn structures, while corn gluten meal had the lowest percentage of $\beta$-turn 
Table 2. Molecular spectral band intensity characteristics of five conventional feed ingredient proteins

\begin{tabular}{lccccccc}
\hline Item & Soybean meal & Fish meal & Corn DDGS & Corn gluten meal & Feather meal & SEM & p value \\
\hline Amide I height & $0.240^{\mathrm{a}}$ & $0.183^{\mathrm{b}}$ & $0.117^{\mathrm{c}}$ & $0.138^{\mathrm{d}}$ & $0.119^{\mathrm{c}}$ & 0.005 & $<0.001$ \\
Amide II height & $0.092^{\mathrm{a}}$ & $0.076^{\mathrm{b}}$ & $0.057^{\mathrm{c}}$ & $0.084^{\mathrm{d}}$ & $0.065^{\mathrm{e}}$ & 0.002 & $<0.001$ \\
Ratio of amide I to II height & $2.619^{\mathrm{a}}$ & $2.413^{\mathrm{b}}$ & $2.057^{\mathrm{c}}$ & $1.645^{\mathrm{d}}$ & $1.842^{\mathrm{e}}$ & 0.021 & $<0.001$ \\
Amide I area & $0.463^{\mathrm{a}}$ & $0.353^{\mathrm{b}}$ & $0.226^{\mathrm{c}}$ & $0.266^{\mathrm{d}}$ & $0.229^{\mathrm{c}}$ & 0.009 & $<0.001$ \\
Amide II area & $0.177^{\mathrm{a}}$ & $0.146^{\mathrm{b}}$ & $0.110^{\mathrm{c}}$ & $0.161^{\mathrm{d}}$ & $0.124^{\mathrm{e}}$ & 0.003 & $<0.001$ \\
Ratio of amide I to II area & $2.618^{\mathrm{a}}$ & $2.420^{\mathrm{b}}$ & $2.064^{\mathrm{c}}$ & $1.646^{\mathrm{d}}$ & $1.848^{\mathrm{e}}$ & 0.021 & $<0.001$ \\
\hline
\end{tabular}

Corn DDGS, corn distiller's dried grains with solubles; SEM, standard error of the mean.

Different lowercase letters in the same line indicate significant differences $(n=3, p<0.05)$.

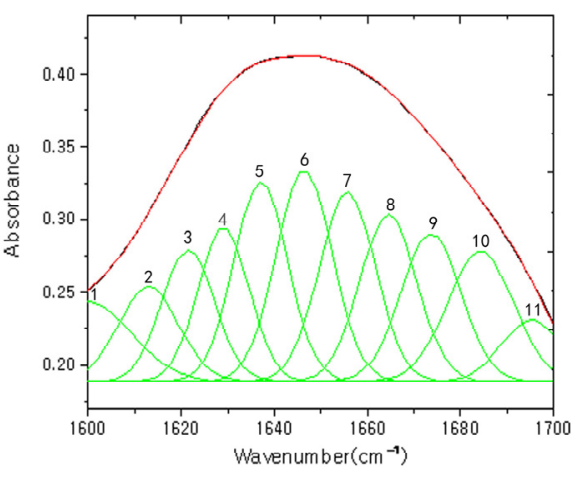

(A)

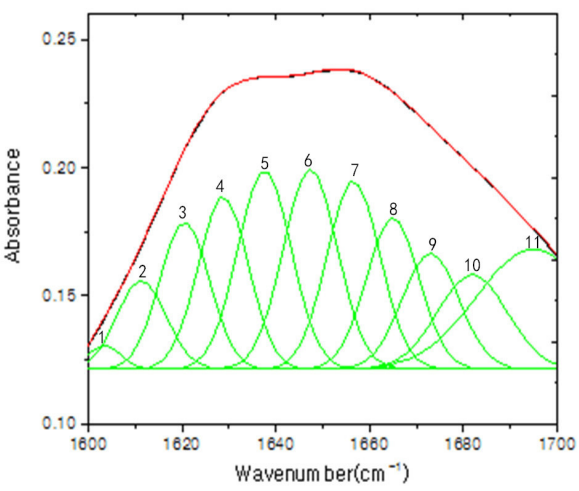

(C)

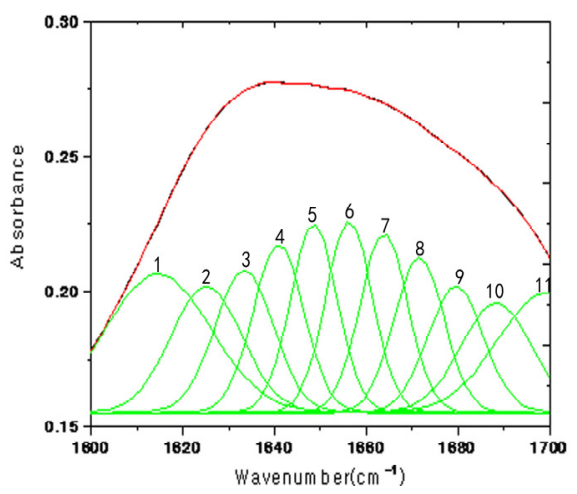

$(\mathrm{E})$

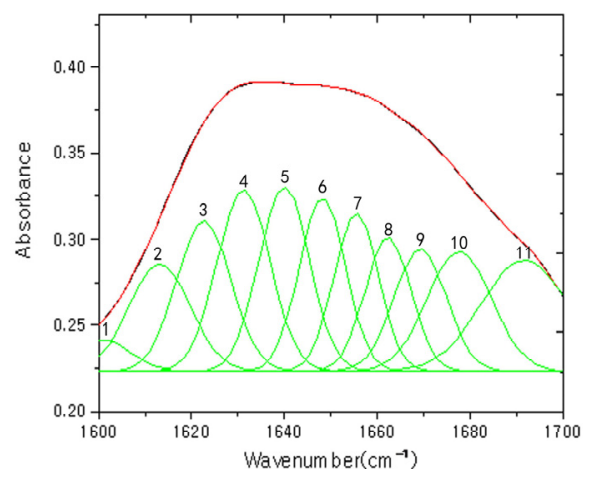

(B)

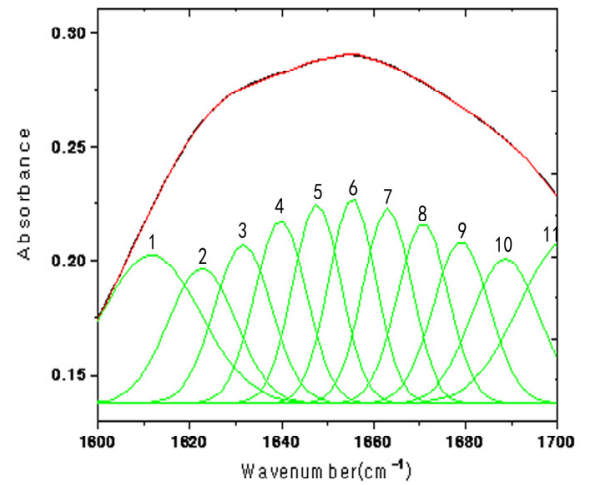

(D)

Figure 2. Curve-fitted individual component bands (A to E) of the amide I region in Fourier transform infrared (FTIR) spectra (1,700 to $1,600 \mathrm{~cm}^{-1}$ ). (A) soybean meal; (B) fish meal; (C) corn distiller's dried grains with solubles (corn DDGS); (D) corn gluten meal; (E) feather meal. Using Fourier self-deconvolution, the positions of 11 sub-peaks were subjected to Gaussian curve-fitting in the amide I band. 
Table 3. Protein solubility and secondary structures of five conventional feed ingredients

\begin{tabular}{lccrcr}
\hline Item & Soybean meal & Fish meal & Corn DDGS & Corn gluten meal & Feather meal \\
\hline $\begin{array}{l}\text { Protein solubility (\% of CP) } \\
\text { Protein secondary structures (\%) }\end{array}$ & $84.19 \pm 0.42^{\mathrm{a}}$ & $33.77 \pm 0.13^{\mathrm{b}}$ & $14.76 \pm 0.02^{\mathrm{c}}$ & $12.31 \pm 0.00^{\mathrm{c}}$ & $8.05 \pm 0.00^{\mathrm{c}}$ \\
$\quad$ & & & & \\
$\quad \alpha$-Helix & $12.16 \pm 0.50^{\mathrm{a}}$ & $10.82 \pm 0.14^{\mathrm{b}}$ & $9.49 \pm 0.33^{\mathrm{c}}$ & $8.66 \pm 0.17^{\mathrm{c}}$ & $8.59 \pm 0.12^{\mathrm{c}}$ \\
$\beta$-Sheet & $33.25 \pm 1.44^{\mathrm{a}}$ & $36.45 \pm 0.86^{\mathrm{b}}$ & $37.05 \pm 0.10^{\mathrm{b}}$ & $36.70 \pm 0.08^{\mathrm{b}}$ & $41.29 \pm 0.84^{\mathrm{c}}$ \\
$\beta$-Turn & $35.95 \pm 1.53^{\mathrm{a}}$ & $39.78 \pm 0.33^{\mathrm{b}}$ & $43.20 \pm 0.71^{\mathrm{c}}$ & $32.20 \pm 0.38^{\mathrm{d}}$ & $39.67 \pm 1.49^{\mathrm{b}}$ \\
Random coil & $12.34 \pm 0.61^{\mathrm{a}}$ & $12.21 \pm 0.07^{\mathrm{a}}$ & $10.68 \pm 0.43^{\mathrm{b}}$ & $8.22 \pm 0.05^{\mathrm{c}}$ & $9.64 \pm 0.45^{\mathrm{b}}$ \\
$\quad$ Ratio of $\alpha$-helix to $\beta$-sheet & $36.57 \pm 0.05^{\mathrm{a}}$ & $29.70 \pm 0.33^{\mathrm{b}}$ & $25.62 \pm 0.82^{\mathrm{c}}$ & $23.58 \pm 0.44^{\mathrm{d}}$ & $20.83 \pm 0.70^{\mathrm{e}}$ \\
\hline
\end{tabular}

Different lowercase letters in the same line indicate significant differences $(\mathrm{n}=3, \mathrm{p}<0.05)$.

and random coil structures. The rank order of PS was soybean meal $>$ fish meal $>$ corn DDGS $>$ corn gluten meal $>$ feather meal $(\mathrm{p}<0.05)$.

\section{Protein in vitro digestibility}

Evaluation of protein in vitro digestibility revealed significant differences among five conventional feed ingredients at each time point $(\mathrm{p}<0.05$; Figure 3$)$. The in vitro digestibility of proteins by pepsin-trysin increased over time. Soybean and feather meal had the highest and lowest in vitro digestibility values, respectively, at $28 \mathrm{~h}$. The rank order of protein in vitro digestibility at this time point was soybean meal $>$ fish meal $>$ corn DDGS $>$ corn gluten meal $>$ feather meal $(\mathrm{p}<0.05)$. The lower in vitro digestibility of corn DDGS proteins at $28 \mathrm{~h}$ as compared to that at $24 \mathrm{~h}$ may be explained by the inhibition of enzymatic reactions due to accumulation of digestion products.

Correlation between protein spectral band intensities and protein in vitro digestibility and solubility

Coefficients of correlation between protein spectral band intensities (height and area) and protein in vitro digestibility at $28 \mathrm{~h}$ as well as solubility are shown in Table 4. Amide I height was positively correlated with PS ( $\mathrm{r}=$ $0.958, \mathrm{p}<0.001)$ and in vitro digestibility $(\mathrm{r}=0.848, \mathrm{p}<$ $0.001)$, as were amide II height $(\mathrm{r}=0.707, \mathrm{p}=0.003$ and $\mathrm{r}=$ $0.518, \mathrm{p}=0.048$, respectively), the height ratio of amide I to II $(\mathrm{r}=0.857, \mathrm{p}<0.001$ and $\mathrm{r}=0.894, \mathrm{p}<0.001$, respectively), amide $\mathrm{I}$ area $(\mathrm{r}=0.959, \mathrm{p}<0.001$ and $\mathrm{r}=$ $0.959, \mathrm{p}<0.001$, respectively), amide II area $(\mathrm{r}=0.709, \mathrm{p}=$ 0.003 and $\mathrm{r}=0.519, \mathrm{p}=0.047$, respectively), and area ratio of amide I to II ( $\mathrm{r}=0.854, \mathrm{p}<0.001$ and $\mathrm{r}=0.893, \mathrm{p}<0.001$, respectively).

\section{Correlation between protein secondary structures and protein in vitro digestibility and solubility}

Coefficients of correlation between protein secondary structures and protein in vitro digestibility at $28 \mathrm{~h}$ as well as solubility are shown in Table 5 . The percentage of $\alpha$-helix structures was positively correlated with PS $(r=0.903$, $\mathrm{p}<0.001)$ and in vitro digestibility $(\mathrm{r}=0.916, \mathrm{p}<0.001)$, as were the percentage of random coil structures $(r=0.694, p$

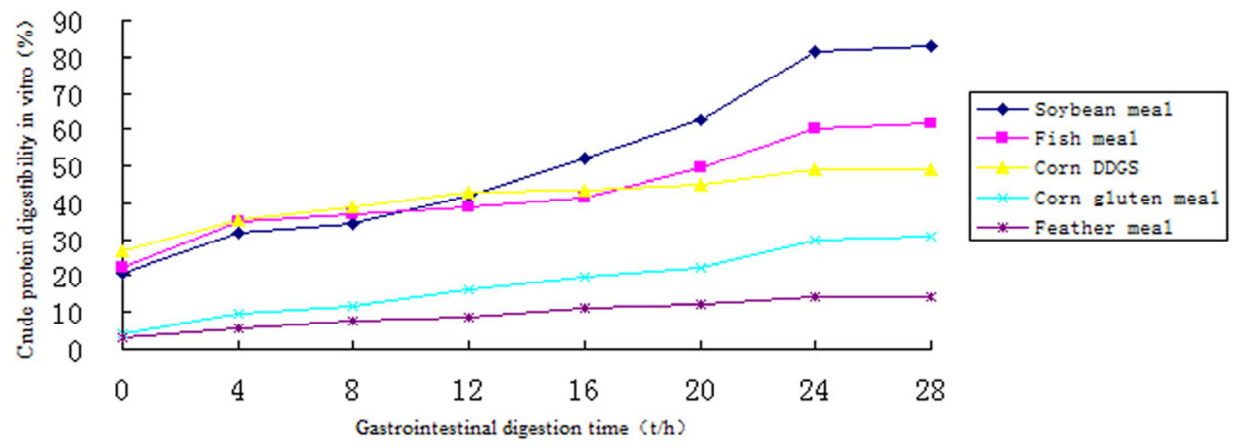

Figure 3. In vitro digestibility of five conventional feed ingredient proteins.

Table 4. Correlations between feed protein spectral band intensity characteristics and protein in vitro digestibility and solubility

\begin{tabular}{|c|c|c|c|c|c|c|c|c|c|c|c|c|}
\hline \multirow{3}{*}{ Item } & \multicolumn{6}{|c|}{ Peak height } & \multicolumn{6}{|c|}{ Peak area } \\
\hline & \multicolumn{2}{|c|}{ Amide I } & \multicolumn{2}{|c|}{ Amide II } & \multicolumn{2}{|c|}{ Height ratio amide I:II } & \multicolumn{2}{|c|}{ Amide I } & \multicolumn{2}{|c|}{ Amide II } & \multicolumn{2}{|c|}{ Area ratio amide I:II } \\
\hline & $\mathrm{R}$ & $\overline{\mathrm{p} \text { value }}$ & $\mathrm{R}$ & $\overline{p \text { value }}$ & $\mathrm{R}$ & $\mathrm{p}$ value & $\mathrm{R}$ & $\overline{\mathrm{p} \text { value }}$ & $\mathrm{R}$ & $\overline{\mathrm{p} \text { value }}$ & $\mathrm{R}$ & $\mathrm{p}$ value \\
\hline \multicolumn{13}{|l|}{ Digestible nutrients } \\
\hline Protein in vitro digestibility & $0.848 * *$ & $<0.001$ & $0.518 *$ & 0.048 & $0.894 * *$ & $<0.001$ & $0.849 * *$ & $<0.001$ & $0.519 *$ & 0.047 & $0.893 * *$ & $<0.001$ \\
\hline Protein solubility & $0.958 * *$ & $<0.001$ & $0.707 * *$ & 0.003 & $0.857 * *$ & $<0.001$ & $0.959 * *$ & $<0.001$ & $0.709 * *$ & 0.003 & $0.854 * *$ & $<0.001$ \\
\hline
\end{tabular}

$\mathrm{R}$, correlation coefficient; $* \mathrm{p}<0.05, * * \mathrm{p}<0.01$.

Correlation coefficient obtained using the Pearson method. 
$=0.004$ and $\mathrm{r}=0.789, \mathrm{p}<0.001$, respectively) and $\alpha$-helixto- $\beta$-sheet ratios $(r=0.955, p<0.001$ and $r=0.966, p<0.001$, respectively). However, the percentage of $\beta$-sheet structures was negatively correlated with both protein in vitro digestibility $(\mathrm{r}=-0.826, \mathrm{p}<0.001)$ and solubility $(\mathrm{r}=-0.740$, $\mathrm{p}=0.002$ ).

\section{DISCUSSION}

There is an increasing demand to improve the nutritional value of feed proteins for monogastric animals by optimizing feed protein sources and increasing the efficiency of protein utilization, which requires a fast and accurate estimation of the intestinal digestibility of feed proteins. Earlier findings suggest that the pepsin-pancreatin two-step enzymatic method is potentially a useful for evaluating in vivo digestibility (Boisen et al., 1995). However, previous studies have been unable to explain the variability in the digestion of different feed proteins, which are likely due to differences in protein structure.

The present study investigated the molecular spectral band characteristics of proteins in various types of feedstuff in relation to their digestibility and solubility. PS and protein spectral band intensities (height and area) in the feedstuff examined in this study varied widely. Protein secondary structures such as $\alpha$-helices, $\beta$-sheets, and random coils as well as $\alpha$-helix-to- $\beta$-sheet ratios in soybean meal and corn DDGS, and the relative quantitative amounts of $\alpha$-helices and $\beta$-sheets in feather meal were inconsistent with earlier findings (Yu et al., 2004; Jiao et al., 2012). Even the reason for these differences is unclear, they may be related to variations inherent in feed sources, processing technology, or storage conditions (Peng et al., 2014).

We found that in vitro digestibility of soybean meal protein was lower than previously reported values (Boisen et al., 1995), which may have been due to the presence of anti-nutritional factors (Tan-Wilson et al., 1985) that can inhibit enzymatic reactions. On the other hand, fish meal protein in vitro digestibility was higher than that reported in another study (Huang et al., 2000) whereas feather meal protein in vitro digestibility was similar to results obtained by other investigators (Yu et al., 2004). This may be due to the presence of keratin - a scleroprotein that makes up $85 \%$ to $90 \%$ of feather meal — which has highly stable S-S and S$\mathrm{H}$ linkages that are not readily broken down by animals without processing (Papadopoulos et al., 1986). One possible reason for which corn DDGS and gluten meal had lower protein in vivo digestibility and PS is their low solubility in water due to a high content of alcohol-soluble proteins containing hydrophobic amino acids (Liu et al., 2013); alternatively, the S-S or O-H bonds in their structures may promote the formation of $\alpha$-helices (Zhang and $\mathrm{Yu}, 2012$ ), which are structurally stable and therefore not easily digested.

The amide I band mainly arises from stretching vibrations of the amide $\mathrm{C}=\mathrm{O}$ group, while the amide II band is attributable to $\mathrm{N}-\mathrm{H}$ bending $(60 \%)$ and $\mathrm{C}-\mathrm{N}$ stretching $(40 \%)$ vibrations; these have also been used to determine protein structure or conformation (Yan et al., 2014), and the protein two primary spectral band intensities in terms of peak height and peak area indicate quantitative differences in protein functional groups (Peng et al., 2014). Corn DDGS and feather meal degraded slowly as compared to the other types of feed due in part to their low basic amino acid content, which is indirectly reflected by amide height and area. Trypsin is the main protease in the intestine and targets the peptide bond between lysine and arginine; therefore, the lack of basic amino acids would diminish the probability of contact between the $\mathrm{CP}$ in feed and digestive enzymes in the animal, thereby decreasing the amount and variety of oligopeptides and free amino acids that are released (Adler-Nissen, 1979).

The vibrational frequency of the amide I band is particularly sensitive to and can be used to predict protein secondary structure (Yu et al., 2004). Our findings confirmed that the percentage of $\beta$-sheet structures is closely related to the nutritional value of feed, with higher percentage being associated with lower PS and CP digestibility in the small intestine, since $\beta$-sheets have a large number of hydrogen bonds that can hinder protease activity. We also confirmed that the nutritional value of proteins feed differed according to $\alpha$-helix-to- $\beta$-sheet ratio; previous studies have also reported that this ratio is a good predictor of nutritional value or digestibility of proteins feed (Theodoridou and Yu, 2013; Xin et al., 2013b). We found that the percentage of random coil structures was positively correlated with PS and digestibility, possibly because this structure is strong and flexible and has fewer hydrogen bonds that can impede enzyme access, which allows proteins to be readily degraded.

Table 5. Correlations between feed protein secondary structures and protein in vitro digestibility and solubility

\begin{tabular}{|c|c|c|c|c|c|c|c|c|}
\hline \multirow{2}{*}{ Digestible nutrients } & \multicolumn{2}{|c|}{$\alpha$-Helix } & \multicolumn{2}{|c|}{$\beta$-Sheet } & \multicolumn{2}{|c|}{ Random coil } & \multicolumn{2}{|c|}{ Ratio of $\alpha$-helix to $\beta$-sheet } \\
\hline & $\mathrm{R}$ & $\mathrm{p}$ value & $\mathrm{R}$ & $\mathrm{p}$ value & $\mathrm{R}$ & $\mathrm{p}$ value & $\mathrm{R}$ & $\mathrm{p}$ value \\
\hline Protein in vitro digestibility & $0.916 * *$ & $<0.001$ & $-0.826^{* *}$ & $<0.001$ & $0.789 * *$ & $<0.001$ & $0.966 * *$ & $<0.001$ \\
\hline Protein solubility & $0.903 * *$ & $<0.001$ & $-0.740 * *$ & 0.002 & $0.694 * *$ & 0.004 & $0.955^{* *}$ & $<0.001$ \\
\hline
\end{tabular}

$\mathrm{R}$, correlation coefficient; * $\mathrm{p}<0.05, * * \mathrm{p}<0.01$.

Correlation coefficient obtained using the Pearson method. 


\section{CONFLICT OF INTEREST}

We certify that there is no conflict of interest with any financial organization regarding the material discussed in the manuscript.

\section{ACKNOWLEDGMENTS}

This study was supported by a grant from the National Key Basic Research Program Fund (973 Program; no. 2013CB127306).

\section{REFERENCES}

Adler-Nissen, J. 1979. Determination of the degree of hydrolysis of food protein hydrolysates by trinitro benzene sulfonic acid. J. Agric. Food Chem. 6:1256-1262.

AOAC. 1990. Official Methods of Analysis. 15th edn. Association of Official Analytical Chemists, Arlington, VA, USA.

Boisen, S. and J. A. Fernandez. 1995. Prediction of the apparent ileal digestibility of protein and amino acids in feedstuffs and feed mixtures for pigs by in vitro analyses. Anim. Feed Sci. Technol. 51:29-43.

Chen, L. M., X. W. Zhang, and P. Q. Yu. 2014. Molecular Spectroscopy Basis to Explore Molecular Structure in Relation to Nutritional Values and Metabolic Characteristics in Dairy Cattle of Chinese DDGS from Different Sources. Ph.D. Tianjin Agricultural University, Tianjin, China.

Dale, N. M., M. Araba, and E. Whittle. 1987. Protein solubility as an indicator of optimum processing of soybean meal. In: Proceedings of 1987 Georgia Nutrition Conference for the Feed Industry, Georgia Nutrition Society, Atlanta, GA, USA. pp. 88-95.

Doiron, K., P. Yu, J. J. McKinnon, and D. A. Christensen. 2009. Heat-induced protein structure and subfractions in relation to protein degradation kinetics and intestinal availability in dairy cattle. J. Dairy Sci. 92:3319-3330.

Dyson, H. J. and P. E. Wright. 1993. Peptide conformation and protein folding. Curr. Opin. Struct. Biol. 3:60-65.

Huang, R. L., Z. L. Tan, T. X. Xing, Y. F. Pan, and T. J. Li. 2000. An in vitro method for the estimation of ileal crude protein and amino acids digestibility using the dialysis tubing for pig feedstuffs. Anim. Feed Sci. Technol. 88:79-89.

Jiao, P. X., D. S. Liu, S. Zheng, and C. D. Chen. 2012. Study on protein secondary structures on the protein degradability of feeds in rumen of dairy cows. Feed Ind. 33:48-51.

Liu, B., P. Thacker, J. McKinnon, and P. Yu. 2013. In-depth study of the protein molecular structures of different types of dried distillers grains with solubles and their relationship to digestive characteristics. J. Sci. Food Agric. 93:1438-1448.

Long, G. H., J. Yuan, H. Pan, Z. Sun, Y. Li, and G. X. Qin. 2015. Characterization of thermal denaturation structure and morphology of soy glycinin by FTIR and SEM. Int. J. Food Prop. 18:763-774.
Meng-Xia, X. and L. Yuan. 2002. Studies on the hydrogen bonding of aniline's derivatives by FT-IR. Spectrochim. Acta A Mol. Biomol. Spectrosc. 58:2817-2826.

Papadopoulos, M. C., A. R. El Boushy, A. E. Roodbeen, and E. H. Ketelaars. 1986. Effects of processing time and moisture content on amino acid composition and nitrogen characteristics of feather meal. Anim. Feed Sci. Technol. 14:279-290.

Peng, Q. H., N. A. Khan, Z. Wang, and P. Q. Yu. 2014. Relationship of feeds protein structural makeup in common Prairie feeds with protein solubility, in situ ruminal degradation and intestinal digestibility. Anim. Feed Sci. Technol. 194:58-70.

Qin, G. X., Z. W. Sun, G. H. Long, T. Wang, and M. M. Bai. 2014. The physicochemical property of feedstuff proteins and its effects on the nutritional value. Chin. J. Anim. Nutr. 26:1-7.

Samadi, K. Theodoridou, and P. Yu. 2013. Detect the sensitivity and response of protein molecular structure of whole canola seed (yellow and brown) to different heat processing methods and relation to protein utilization and availability using ATRFT/IR molecular spectroscopy with chemometrics. Spectrochim. Acta A Mol. Biomol. Spectrosc. 105:304-313.

Tan-Wilson, A. L., P. M. Hartl, N. E. Delfel, and K. A. Wilson. 1985. Differential expression of Kunitz and Bowman-Birk soybean proteinase inhibitors in plant and callus tissue. Plant Physiol. 78:310-314.

Theodoridou, K. and P. Yu. 2013. Application potential of ATRFT/IR molecular spectroscopy in animal nutrition: Reveal protein molecular structures of canola meal and presscake, as affected by heat processing methods, in relationship with their protein digestive behavior and utilization for dairy cattle. J. Agric. Food Chem. 61:5449-5458.

Xin, H., X. Zhang, and P. Yu. 2013a. Using synchrotron radiationbased infrared microspectroscopy to reveal microchemical structure characterization: frost damaged wheat vs. normal wheat. Int. J. Mol. Sci. 14:16706-16718.

Xin, H., K. C. Falk, and P. Yu. 2013b. Studies on Brassica carinata seed. 1. Protein molecular structure in relation to protein nutritive values and metabolic characteristics. J. Agric. Food Chem. 61:10118-10126.

Yan, X., N. A. Khan, F. Zhang, L. Yang, and P. Yu. 2014. Microwave irradiation induced changes in protein molecular structures of barley grains: relationship to changes in protein chemical profile, protein subfractions, and digestion in dairy cows. J. Agric. Food Chem. 62:6546-6555.

Yu, P., J. J. Mckinnon, C. R. Christensen, and D. A. Christensen. 2004. Using synchrotron-based FTIR micro-spectroscopy to reveal chemical features of feather protein secondary structure: comparison with other feed protein sources. J. Agric. Food Chem. 52:7353-7361.

Yu, P. and W. G. Nuez-Ortín. 2010. Relationship of protein molecular structure to metabolisable proteins in different types of dried distillers grains with solubles: A novel approach. Br. J. Nutr. 104:1429-1437.

Zhang, X. and P. Yu. 2012. Molecular basis of protein structure in combined feeds (hulless barley with bioethanol coproduct of wheat dried distillers grains with solubles) in relation to protein rumen degradation kinetics and intestinal availability in dairy cattle. J. Dairy Sci. 95:3363-3379. 